\title{
ПАЛЕОПОТАМОЛОГИЯ ПЛЕЙСТОЦЕНОВЫХ ОТЛОЖЕНИЙ В БАРГУЗИНСКОЙ ДОЛИНЕ (БАЙКАЛЬСКАЯ РИФТОВАЯ ЗОНА)
}

\author{
А. И. Хассан ${ }^{1,2}$, В. Л. Коломиец ${ }^{3,4}$, С. В. Рассказов ${ }^{1,5}$, \\ Р. Ц. Будаев ${ }^{3}$, И. С. Чувашова ${ }^{1,5}$, А. Аль Хамуд ${ }^{1,6}$ \\ ${ }^{1}$ Иркутский государственный университет \\ ${ }^{2}$ Университет Аль-Басс, г. Хомс, Сирия \\ ${ }^{3}$ Геологический институт СО РАН, Улан-Удэ \\ ${ }^{4}$ Бурятский государственный университет им. Д. Банзарова, Улан-Удэ \\ ${ }^{5}$ Институт земной коры СО РАН, Иркутск \\ ${ }^{6}$ Университет Аль-Фурат, Дейр-Эз-Зор, Сирия
}

Поступила в редакцию 1 ноября 2019 г.

\begin{abstract}
Аннотация: в статье приводятся результать гранулометрического исследования 527-метрового разреза отложений в урочище Верхний Куйтун Баргузинской долины (172 м естественного обнажения и 355 м керна скважины), включающего нижнюю ритмичную галечно-песчаную и верхнюю песчаную толщи. Ритмичная толщза представляет собой русловой аллювий, накопившийся одновременно с быстрым (некомпенсированным осадками) погружением ложа оз. Байкал. Верхняя песчаная толща образовалась в результате особого режима аккумуляции обломочного материала, доминировавшего в Баргузинской долине до Тыйской тектонической фазы структурной перестройки рельефа кониа среднего неоллейстоиена. Из палеопотамологического анализа результатов мы делаем вывод о накоплении песчаной толщчи в неглубоких проточных лимнических водоемах со слабым волнением и придонным течением (субгоризонтально-слоистье алеврить и тонкозернистые пески береговых и прибрежных фаций озер), а также поступательными немобильными речными потоками с подпорным, замедленным движением воды (мелко-среднезернистые пески с наклонной и косой текстурой русловых и пойменных фаций рек).
\end{abstract}

Ключевые слова: Байкал, Баргузинская долина, плейстоцен, литогенез, гранулометрический анализ, пески, аллювий, озерные отложения.

\section{PALEOPOTAMOLOGY OF PLEISTOCENE SEDIMENTS IN THE BARGUZIN VALLEY (BAIKAL RIFT ZONE)}

\author{
A. I. Hassan ${ }^{1,2}$, V. L. Kolomiets ${ }^{3,4}$, S. V. Rasskazov ${ }^{1,5}$, \\ R.Ts. Budaev ${ }^{3}$, I. S. Chuvashova ${ }^{1,5}$, A. Al Hamoud ${ }^{1,6}$ \\ ${ }^{1}$ Irkutsk State University, Irkutsk \\ ${ }^{2}$ Al-Baath University, Homs, Syria \\ ${ }^{3}$ Geological Institute SB RAS, Ulan-Ude \\ ${ }^{4}$ D. Banzarov Buryat State University, Ulan-Ude \\ ${ }^{5}$ Institute of the Earth's Crust, Siberian Branch of RAS, Irkutsk \\ ${ }^{6}$ Al-Furat University, Deir ez-Zor, Syria
}

Received 1 November 2019

\begin{abstract}
Upper Kuytun sedimentary section: $172 \mathrm{~m}$ of natural outcrop and $355 \mathrm{~m}$ of core material from a drill hole. The section exhibits the lower rhythmic pebble-sandy and upper sandy stratums. The former accumulated in Barguzin Valley during a rapid (uncompensated by sedimentation) subsidence of the Lake Baikal bed. The latter formed due to specific regime of sediment accumulation that occurred before the Tyya tectonic phase of
\end{abstract}

() Hassan A. I., Kolomiets V. L., Rasskazov S. V., Budaev R.Ts., Chuvashova I. S., Hamoud A. Al., 2019 Контент доступен под лицензией Creative Commons Attribution 4.0 License.

The content is available under Creative Commons Attribution 4.0 License. 
relief structural reorganization at the end of the Middle Neopleistocene. From paleopotamological analysis of data obtained, we infer that the sandy stratum accumulated in shallow flow lacustrine reservoirs with weak waves and bottom currents (subhorizontally-layered siltstones and fine-grained sands of coastal and littoral facies of lakes), as well as progressive immobile river flows with retaining, sloweddown movement of water (fine-medium-grained sands with oblique and floodplain facies of rivers).

Keywords: Baikal, Barguzin Valley, Pleistocene, lithogenesis, granulometric analysis, sands, alluvial sediments, lacustrine sediments.

\section{Введение}

Баргузинская долина - одна из осевых структур Байкальской рифтовой зоны - обрамлена горными поднятиями Баргузинского и Икатского хребтов. По характеру осадконакопления во впадинах в новейшей истории рифтовой зоны различались два этапа: раннеорогенный медленных движений и позднеорогенный ускоренных движений [1]. По интерпретации геофизических данных [2, 3], Баргузинская долина состоит из четырех котловин (с юго-запада на северовосток): Джидинской, Усть-Миндайской, Хонхинской и Усть-Гаргинской. Максимальная глубина 2,5 км определена в Хонхинской котловине, в которой четвертичные отложения были вскрыты глубокой скв. Р1. Галечники, глины и пески общей мощностью 408 м составляли нижнечетвертичную толщу, а вышележащие песчанистые глины, разнозернистые пески с примесью гальки и гравия мощностью 306 м среднечетвертичную толщу, образующую куйтуны. Общая мощность среднечетвертичной толщи по ее положению в рельефе, превысила 520 м [4, 5].

В днище Баргузинской долины выделяются три основных элемента строения рельефа: а) наклонноволнистая равнина подножия Баргузинского хребта, б) террасовый комплекс р. Баргузин и в) песчаные увалы (куйтуны) подножия юго-восточного макросклона Икатского хребта. Увалы имеют отчетливое морфологическое выражение и представлены Лесным, Верхним и Нижним Куйтунами (до 200 м относительной высоты), которые разделены между собой долинами рр. Гарга и Аргада. Массивы выполнены толщами алевритово-псаммитового материала комплексного озерно-речного и речного происхождения с примесью фаций пролювиального, делювиального и эолового генезиса.

Выявление обстановок морфо- и седиментогенеза песчаных толщ суходольных межгорных впадин Байкальской рифтовой зоны, в том числе Баргузинской долины, - одна из нерешенных проблем плейстоценовой истории региона, так как от определения происхождения этих толщ зависит трактовка эволюции рельефа территории юга Сибири. Толщи распространены в речных долинах и межгорных впадинах, которые дренируются реками стока к оз. Байкал.

В настоящей работе рассматриваются условия последовательного накопления в Баргузинской долине аллювиального и озерного плейстоценовых стратонов, выявленные по результатам палеопатомологического анализа отложений, вскрытых в 2012 г. скважиной 538 Байкальского филиала «Сосновгеология» ФГУГП «Урангеологоразведка» и изученных в естественных обнажениях в районе Аргадинского отрога (рис. 1).

\section{Методы исследований}

Размер частиц - важный структурный признак, который отражает динамические условия переноса и отложения материала. При изучении осадочного чехла Баргузинской долины использовался гранулометрический анализ, как метод фациальных и палеогеографических реконструкций. Гранулометрический анализ проведен с использованием сит КСИ и получением фракций - частиц какой-либо одной градации. Основные формулы, использованные при обработке данных с помощью математической статистики и палеопотамологических реконструкций, взяты из работы [6].

\section{Результаты работ и обсуждение}

Отложения правобережья р. Аргада

Песчаная толща увала Верхний Куйтун (высота 190-200 м) исследована в районе с. Аргада. На правобережье р. Аргада радиотермолюминесцентным датированием определен возраст ее формирования, начиная с 172 м над урезом воды: 171 м - 140000 20000 л.н. (ГИН СО РАН-587), 168 м - 234000 23000 л.н. (ГИН СО РАН-584), 42 м - 300000 28000 л.н. (ГИН СО РАН-589), 34 м - 310000 \pm 28000 л.н. (ГИН СО РАН-591), 29 м - 380000 \pm 32000 л.н. (ГИН СО РАН592), 24 м - 460000 \pm 40000 л.н. (ГИН СО РАН-593), 19 м $->830000$ л.н. (ГИН СО РАН-594) и 6 м ->790000 л.н. (ГИН СО РАН-595) [7]. Песчаная тоща начала накапливаться до Тыйской тектонической фазы перестройки рельефа [8].

Самая верхняя 15-метровая часть этой толщи сформирована мелко-среднезернистыми (средневзвешенный размер частиц, $\mathrm{x}=0,42-0,46)$ и среднемелкозернистыми (x=0,47-0,5) песками (рис. 2, a). Текстура субгоризонтальная и наклонная, мощность слойков - 2-6 см. Значения коэффициента сортировки песков (стандартное отклонение, $\sigma=0,23-0,31$ ) характеризуют осадки как хорошо и умеренно сортированные, что указывает на длительную транспортировку перед их отложением. Статистический коэффициент асимметрии $\alpha>1$ определяет смещение модального параметра в сторону крупнозернистых частиц и тестирует динамику среды осадконакопления на этот временной промежуток как относительно высокую. 


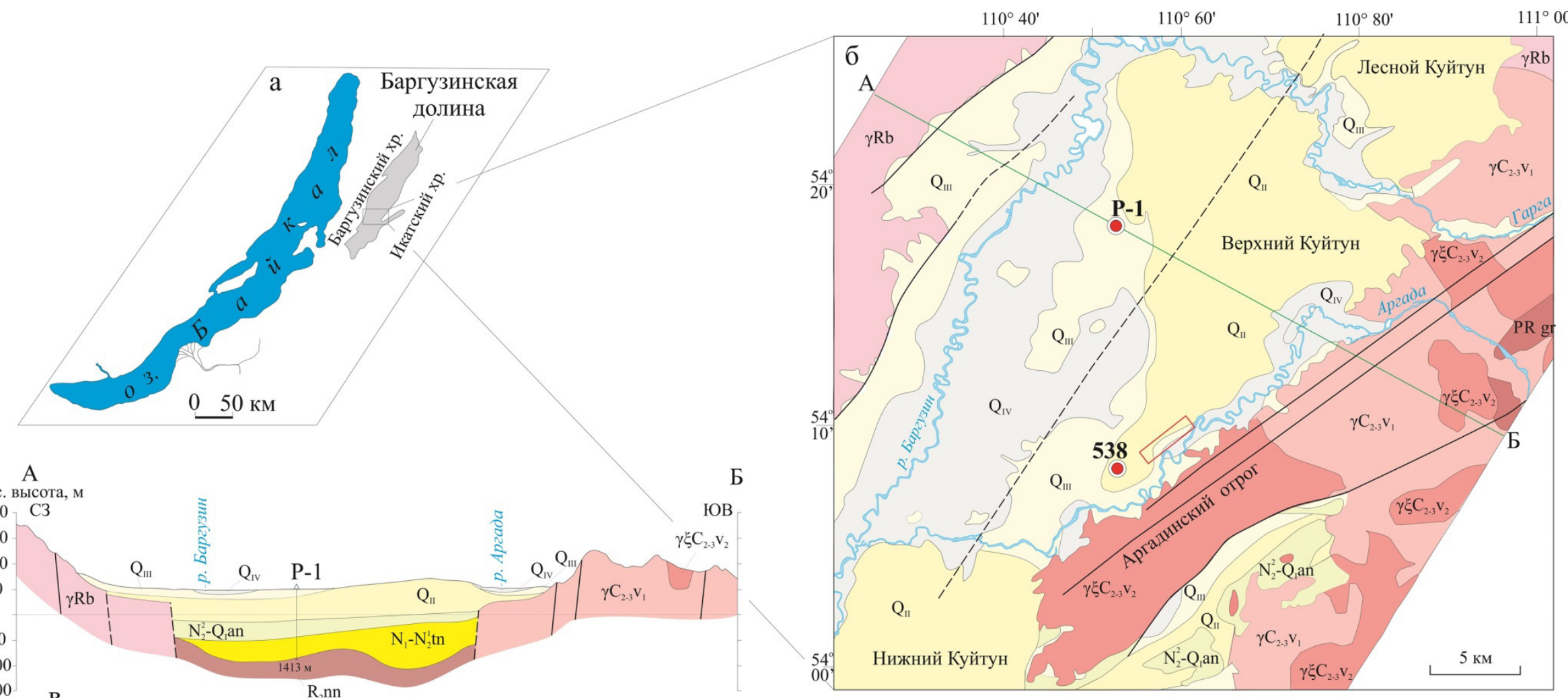

B

$\mathrm{R}_{2} \mathrm{nn}$

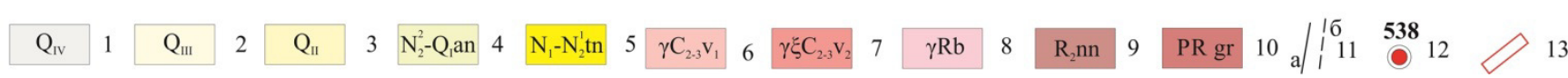

Puc. 1. Местоположение района исследований в Баргузинской долине относительно оз. Байкал (a), на геологической схеме района Аргадинского отрога (б) и геологический разрез по линии АБ (в): 1-3 - четвертичные осадочные отложения: 1 - пойменные, 2 - аллювий надпойменных террас, 3 - аллювиально-озерные; 4 - аносовская свита, 5 - танхойская свита; 6-10 - породы фундамента: 6-7 - витимканский интрузивный комплекс первой (6) и второй (7) фаз, 8 - баргузинский интрузивный комплекс, 9 - няндонинская свита; 10 - гаргинская свита; 11 - крупный разлом выраженный в рельефе (a) и скрытый под чехлом четвертичных отложений (б); 12 - номер и местоположение скважины; 13 - местоположение расчистки песчаного уступа. 

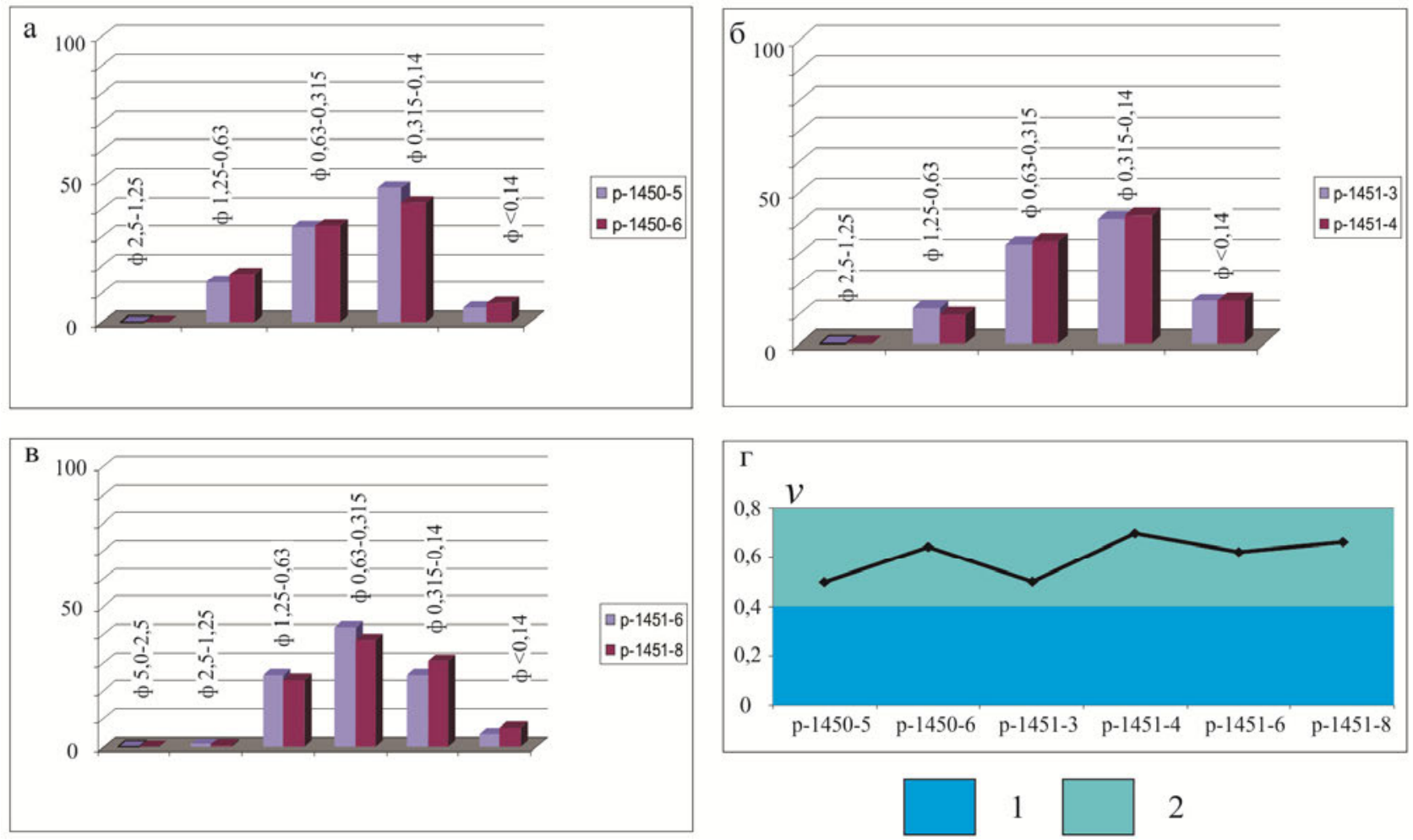

Puc. 2. $a-8$ - гранулометрический состав осадков (a) - по образцам p-1450-5 и р-1450-6 (верхняя толща), (б) - по образцам р-1451-3 и р-1451-4 (нижняя толща) и (в) - по образцам р-1451-3 и р-1451-4 (основание толщи); (2) - сопоставление значений коэффициента вариаций $v$ в пробах отложений урочища Верхний Куйтун: 1 - отложения лимнического генезиса; $2-$ отложения комплексного лимно-аллювиального генезиса.

Эксцесс в равных долях положительный $(\tau=0,46-1,86)$ и отрицательный $(\tau=-0,2--0,6)$, что в первом эпизоде свидетельствует о непрестанном поступлении вещества в седиментационный бассейн, устойчивой скорости его обработки на относительно спокойном тектоническом фоне, во втором - дополнительном приносе обломочного субстрата при нестабильном тектоническом режиме. Показатели коэффициента изменчивости $v$ по всей толще соотносятся с диапазоном 0,50,64 , принадлежащему полю перекрытия лимнической и флювиальной групп аквального парагенетического ряда (рис. 2, 2).

На основании проведенных палеопотамологических реконструкций установлена палеосреда аккумуляции наносов, которая представляла собой стационарный озерный проточный водоем. Его притоки речного облика, перемещавшие осадки по предельному диаметру подвижных частей от крупно- до грубокрупнозернистых песков, имели поверхностные скорости течения $0,5 \mathrm{~m} / \mathrm{c}$, срывающие скорости $0,35 \mathrm{~m} / \mathrm{c}$, придонные скорости отложения $0,23 \mathrm{~m} / \mathrm{c}$, уклоны водного зеркала 0,96-1,35 м/км, глубины: в межень $-0,26$ м, половодье - 2 м и ширину русел 117-132 м.

Малоподвижные ( $\varphi$-критерий устойчивости русел $<100$ единиц) русла полугорного типа (число Фруда, $\mathrm{Fr}=0,10-0,12)$ с площадью водосбора $>100 \mathrm{kм}^{2}$ этих водотоков находились в естественных, благоприятных условиях состояния ложа со свободным течением воды (коэффициент шероховатости, $\mathrm{n}>35$ ). Значения числа Лохтина $(\Lambda=1,47-1,54)$ указывают на незначительное отдаление потоков от конечного водоема в придельтовых условиях.

Нижняя часть осадочной толщи тобольского времени (от 300000 до 380000 тыс. л.н., мощность 20 м) образована наклонно-слоистыми ожелезненными средне-мелкозернистыми $(\mathrm{x}=0,36-0,37$ мм) песками с хорошей сортировкой $(\sigma=0,25)$ (рис. $2, \sigma)$. Для эмпирического полигона фракционных распределений частиц характерной особенностью является его левосторонняя скошенность, возникшая вследствие выборочной обработки в процессе транзита крупнозернистых фракций при повышенной динамике среды седиментации $(\alpha>1)$. Эксцесс положителен $(\tau=1,51-$ $3,29)$. Значения коэффициента вариации находятся в интервале от 0,5 до 0,7 и соответствуют преобладающим условиям аккумуляции в стационарных лимнических акваториях с проточным режимом (рис. 2, г).

Транспортировавшая в неглубокий постоянный озеровидный бассейн седиментации наносы река ПраАргада характеризовалась скоростными параметрами: течения $0,48 \mathrm{~m} / \mathrm{c}$, сдвига $0,34 \mathrm{~m} / \mathrm{c}$, отложения $0,22 \mathrm{~m} / \mathrm{c}$, имела уклон водного зеркала $0,76-0,81$ м/км, меженную глубину 0,3 м при возрастании в половодье до 2,2 м и ширину русла 139-142 м в момент его полного заполнения до выхода воды на пойму. Палеоводотоку нединамичного ( равнинного типа $(\mathrm{Fr}=0,08)$ с площадью водосбора $>100$ $\mathrm{kм}^{2}$ были свойственны натуральные, благоприятные, 
придельтовые $(\Lambda=1,59)$ условия состояния ложа со свободным течением воды $(\mathrm{n}=39)$. Кроме того, по показателям универсального критерия Ляпина $(\beta=0,28)$ устанавливается присутствие в палеорусле подвижных форм низкогрядового рельефа высотой 0,14 м, длиной 1,6 м и скоростью перемещения $0,0002 \mathrm{~m} / \mathrm{c}$.

Самая нижняя часть массива (до 13 м), сформированная на границе эоплейстоцена и неоплейстоцена, выполнена слабонаклонными мелкослоистыми, крупно-мелко-среднезернистыми песками ( $\mathrm{x}=0,5$ мм) умеренной сортировки $(\sigma=0,31-0,32)$, асимметричными с доминантным модальным сдвигом в сторону крупных частиц $(\alpha>1)$ (рис. 2, в). Осадки имеют плюсовой эксцесс и значения коэффициента вариации $(v=0,62-$ $0,66)$, совпадающие с сектором совокупного озерноречного генезиса (рис. 2, г).

Процесс седиментации осуществлялся блуждающими средними водотоками полугорного грядового $(\mathrm{Fr}=0,12)$ типа с естественными стабильными руслами (площадь водосбора $>100 \mathrm{kм}^{2}$ ) в благоприятных условиях состояния ложа и течения воды $(\mathrm{n}>37)$ при впадении в конечный водоем $(\Lambda=1,47)$. Им был свойствен незначительный уклон продольного профиля $1,3 \%$, скорость транспортировки частиц $0,36 \mathrm{~m} / \mathrm{c}$, придонная скорость отложения $0,3 \mathrm{~m} / \mathrm{c}$, скорость течения воды $0,54 \mathrm{~m} / \mathrm{c}$, минимальная глубина 0,25 м при росте высоты столба полых вод до 2 м и ширине в 117 метров на момент максимального заполнения водой. Помимо гладкой фазы влечения наносов по горизонтальной поверхности руслового ложа, здесь же присутствовали низкие гряды высотой 0,12 м, длиной 1,4 м и скоростью перемещения 0,26 мм/c, которые сформировали плоскостную малонаклонную текстуру осадков (номограмма Ржаницына, VVI порядок потока).

\section{Отложения скв. 538}

Байкальским филиалом «Сосновгеология» ФГУГП «Урангеологоразведка» в 2012 г. до глубины 355 м пробурена скважина № 538 (рис. 3). Вскрытые отложения наращивают нижнюю часть разреза осадочной толщи увала Верхний Куйтун.

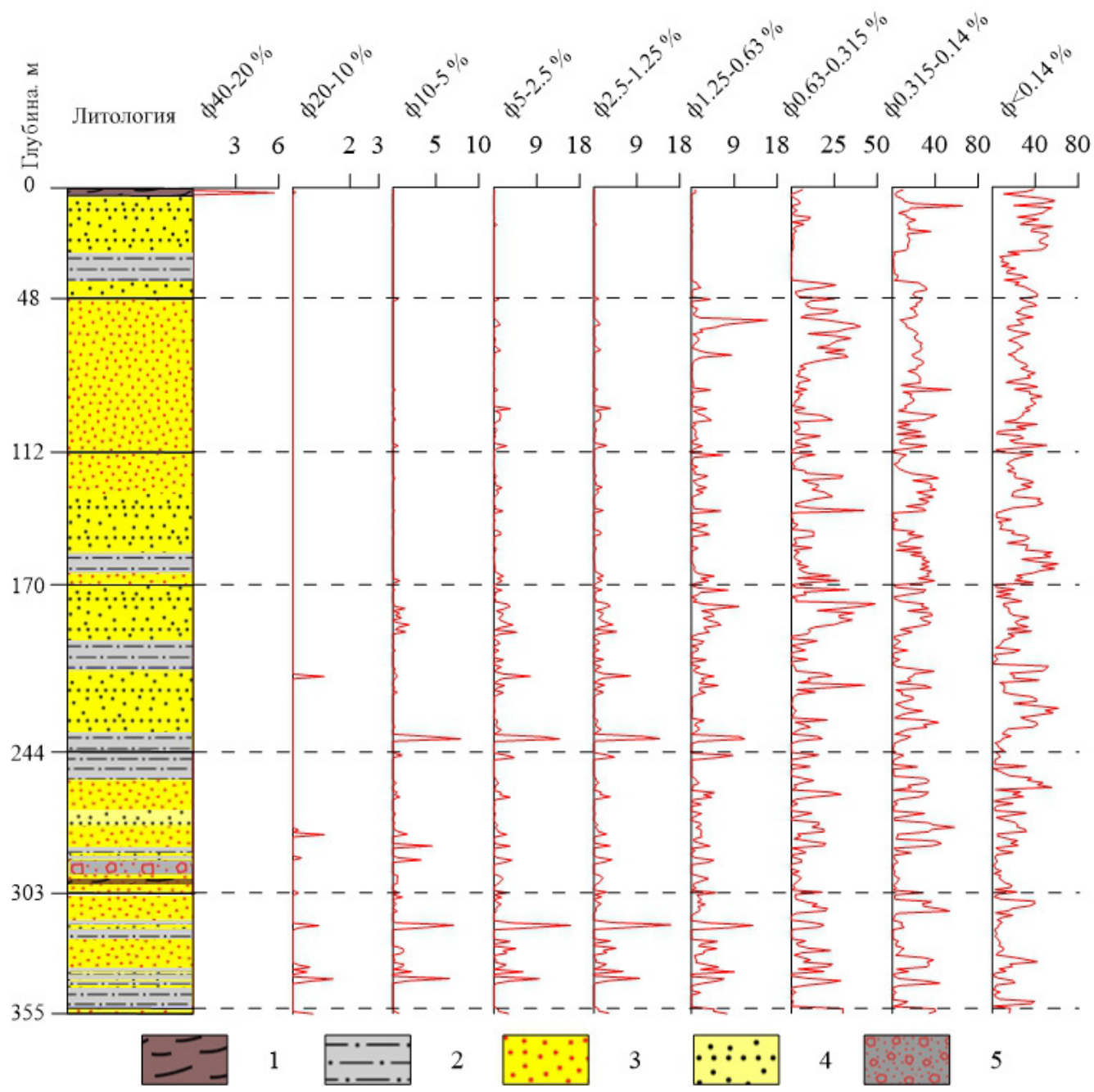

Puc. 3. Результаты гранулометрического анализа неоплейстоценовых отложений, вскрытых скв. 538: 1 - отложения аквального генезиса с примесью осадков неаллювиального происхождения; 2 - отложения комплексного лимно-аллювиального происхождения; 3 - аллювиальные отложения; 4 - ритмичное чередование по вертикали разреза осадков комплексного и речного генезиса; 5 - пролювиальные и склоновые отложения. 
Перекрывающая разрез толща в интервале 0,0-2,0 м состоит из алевропесков и мелкозернистых песков с добавлением гравийно-галечного материала (до 7 \%) как аллювиального $(v<2,0)$, так и аквального генезиса с примесью осадков, отличных от речного происхождения $(v>2,0)$.

Рыхлая толща в интервале 2,0-47,0 м представлена песками различной структуры - песчаными алевритами $(\mathrm{x}=0,08-0,11 \mathrm{Mм})$, алевропесками $(\mathrm{x}=0,12-0,14 \mathrm{Mм})$, алевритисто- и алевритово-мелкозернистыми песками $(\mathrm{x}=0,18-0,26$ мм), а также мелкозернистыми и среднемелкозернистыми их разностями ( $\mathrm{x}=0,27-0,31$ мм) с незначительным включением (до 1 \%) обломков гравийной размерности. Отложения характеризуются особенно хорошей, совершенной и умеренной сортировкой $(\sigma=0,06-0,44)$, асимметричным распределением со сдвинутой в сторону крупных частиц модой. Динамика седиментации при их накоплении была невысокой ( $\alpha$ в среднем около 2 единиц), тектонические условия относительно стабильные (эксцесс $\tau$ главным образом в пределах первого десятка единиц). Коэффициент вариации определяет генезис данных осадков $(v=0,43-0,8)$, как аквальный (поле совмещения лимнических и аллювиальных условий формирования осадков) (рис. 4, а).
Наносы аккумулировались в неглубоких мелководных (до 3,4 м) озерных проточных водоемах. Реки, доставлявшие в седиментационный бассейн осадки, имели слабоподвижные ( $<100)$ русла равнинного типа $(\mathrm{Fr}=0,01-0,08)$ с площадью водосбора $>100 \mathrm{kм}^{2}$ в естественных, благоприятных условиях состояния ложа со свободным течением воды $(\mathrm{n}>40)$. Параметры числа Лохтина $(\Lambda=1,7-1,8)$ свидетельствуют о приближении исследуемых водотоков к конечному водоему (придельтовые условия), чем, по-видимому, обусловлена некоторая изменчивость ширины русел за счет деления единого более крупного русла (130-217 м) на ряд рукавов (34-80 м).

Отложения в интервале 48,0-112,0 м - перемежающиеся слои разнозернистого псаммитового материала с добавками (до 3 \%) мелкогравийных обломков $(\mathrm{x}=0,18-0,66$ мм). Особенно изменчивым становится состав песчаных пород в интервале 100-112 м - чередование по вертикали крупно-среднезернистых, средне-мелкозернистых, алевритово-мелкозернистых песков, алевропесков и песчаных алевритов. Наблюдается общее «огрубение» осадка, по сравнению с толщей в интервале 2,0-47,0 м, что выражается в росте значений статистических параметров седиментации ухудшении сортировки (от хорошей до умеренной и
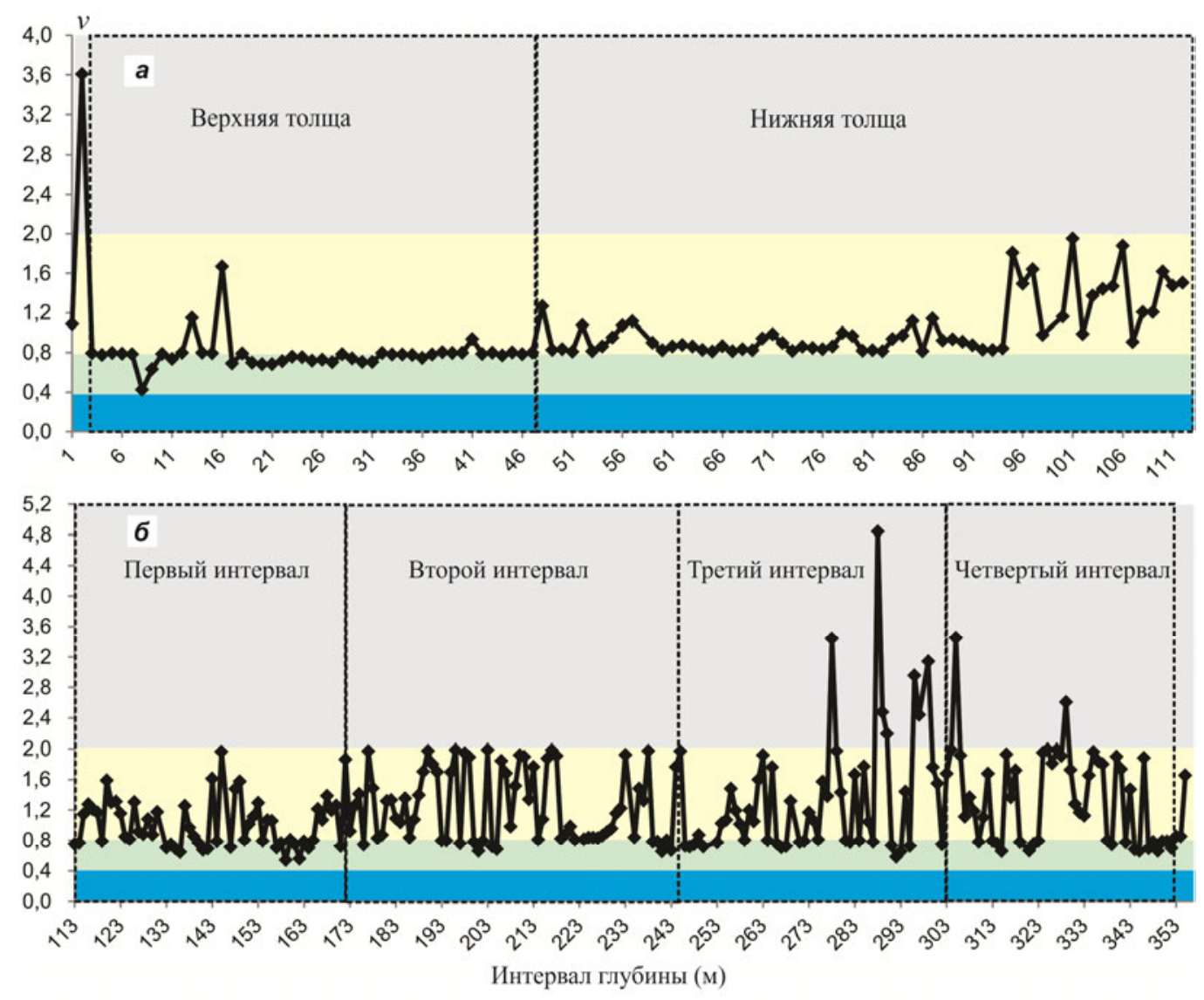

Puс. 4. Сопоставление значений коэффициента вариаций в пробах отложений Баргузинской долины скв. 538 в интервале глубин 0,5-112 м (a) и 113-355 м (б): 1 - отложения озерного генезиса; 2 - отложения комплексного лимно-аллювиального генезиса; 3 - отложения аллювиального генезиса; 4 - отложения неаллювиального генезиса. 
недостаточной, $\sigma=0,15-0,82)$, росте энергетического потенциала, вызвавшего ярко выраженный модальный перекос в сторону крупных частиц в эмпирическом полигоне распределений ( $\alpha$ до 9 единиц). Для тектонического фона характерно изменение его состояния в сторону стабилизации с увеличением глубины разреза (от первого десятка до десятков единиц). Вся без исключения толща имеет аллювиальный генезис $(v=0,81-1,95)$ - от более спокойных турбулентных условий формирования осадков в речных условиях в верхней части до усиления динамических процессов к низу толщи и наибольшим контрастом $(v=0,91-1,88)$ в интервале $100-112$ м (рис. 4, $a)$.

Накопление осадков осуществлялось преимущественно большими и средними палеореками шириной до 340 м (в среднем 130-180 м), характеризующимися в основном равнинным $(\mathrm{Fr}=0,02-0,10)$, реже полугорным $(\mathrm{Fr}=0,11-0,16)$ типами естественных блуждающих русел с площадью водосбора $>100$ км $^{2}$ в благоприятных и весьма благоприятных условиях состояния ложа и свободного течения воды $(\mathrm{n}=36$ 46). Следовательно, осадки, образовавшиеся в исходных условиях, по фациально-генетической природе относятся к аллювиальным русловым грядовым и в меньшей степени - пойменным пескам речной макрофации.

В интервале 113-114 м залегает горизонт особенно хорошо сортированных песчаных алевритов комплексного генезиса, формировавшихся при устойчивом тектоническом фоне $(\mathrm{x}=0,08-0,09$ мм; $\sigma=0,06$ $0,07 ; v=0,75-0,77 ; \tau=32,41-95,96)$.

Далее, до глубины 170 м, осадочная толща сформирована ритмичным залеганием песков четырех ритмов (рис. $4, \sigma)$ - речного $(1, v=0,82-1,31)$, чередующегося между собой речного и комплексного лимно-аллювиального $(2, v=0,64-1,29)$, смешанного озерно-речного $(3, v=0,54-0,8)$ и аллювиального (4, $v=1,07-1,39)$.

Первый ритм (113-131 м) - песчаные породы разной структуры: алевропески ( $\mathrm{x}=0,10-0,16$ мм), пески с доминированием мелкозернистых частиц $(\mathrm{x}=0,22-0,27$ мм) среднезернистые и близкие к ним по составу $(\mathrm{x}=0,38-0,59$ мм). Преобладает хорошая до умеренной сортированность $(\sigma=0,16-0,56)$, левосторонний модальный сдвиг и переменные тектонические условия от стабильных к менее стабильным. Среда осадконакопления - стационарный водоток равнинного, реже полугорного типов средних рек с ложем, выработанным в рыхлых породах, и поступательным движением воды от истока к устью.

Второй ритм (132-156 м) состоит из перемежающихся по вертикали в различных комбинациях песчаных алевритов $(\mathrm{x}=0,08-0,10$ мM), алевропесков $(\mathrm{x}=0,14-0,15 \mathrm{Mм})$, алевритово-мелкозернистых $(\mathrm{x}=$ 0,21-0,23 мм), средне-мелкозернистых ( мм) и среднезернистых, а также средне-крупнозернистых песков ( последовательно 12 смен условий седиментации - от комплексных до речных.

Третий ритм (157-165 м) представлен алевритовомелкозернистыми $(\mathrm{x}=0,24-0,29$ мм $)$ и среднемелкозернистыми песками $(\mathrm{x}=0,30-0,38$ мм), накапливавшимися в условиях проточного неглубокого (1,5-2,6 м) озеровидного водоема.

В четвертом ритме (166-170 м) преобладают мелко-среднезернистые пески ( $\mathrm{x}=0,31-0,69$ мм), формировавшиеся водотоками равнинного $(\mathrm{Fr}=0,06-0,10)$ полугорного $(\mathrm{Fr}=0,15-0,17)$ типов.

В интервале 171-244 м наблюдается развитие слоистой толщи, имеющей трехчленное строение (рис. $4,6)$. Венчающие и подстилающие слои представлены песками речного происхождения $(v=0,83-1,97)$, состоящими из частиц мелкой, средней и крупной размерности ( $\mathrm{x}=0,23-1,59$ мм) разной степени сортировки, левосторонним модальным смещением в сторону крупных частиц и их хорошим структурированием, тектонический фон - стабильный устойчивый. Аккумуляция осадков осуществлялась речными потоками преимущественно средней величины (40-200 м) равнинного $(\mathrm{Fr}=0,03-0,09)$ и полугорного $(\mathrm{Fr}=0,11-0,30)$ типов в благоприятных условиях состояния ложа и течения при близком положении устья $(\Lambda=1,3-2,6)$. Для палеоводотоков полугорного типа свойственно возрастание гидродинамических параметров - ширины до 580 м. Скорость течения составляла 0,6-0,8 м/с, глубина - 3-7 м, уклон продольного профиля - 1,43,1 м/км. Средний горизонт сложен песчаными алевритами, алевритово-, тонко- и мелкозернистыми песками с небольшими добавками более крупных частиц ( $\mathrm{x}=0,08-0,33$ мм). Преобладают осадки лимно-аллювиального происхождения $(v=0,66-0,80)$, формировавшиеся в озеровидных мелководных (1,0-1,6 м) бассейнах. Такими же структурно-генетическими и динамическими свойствами обладает горизонт песчаных алевритов комплексного происхождения, залегающий на разделе (интервал 239-243 м) с нижележащей толщей.

Толща в интервале 244-302 м представлена разными по мощности ритмами (до шести, сверху вниз) неоднородного генезиса (рис. 4, б):

В первом ритме (интервал 244-253 м) преобладают алевритово-тонкопесчаные породы $(\mathrm{x}=0,08$ 0,31 мм), сменяющиеся крупно-среднезернистым песком ( $\mathrm{x}=0,44-0,60 \mathrm{Mм})$. По стандартному отклонению $(\sigma=0,05-1,06)$ осадки хорошо, умеренно, реже - плохо сортированы с модальным перекосом в сторону крупных частиц $(\alpha>1)$ и положительным эксцессом.

Коэффициент вариации $(v=0,87-1,97)$ указывает на аллювиальное происхождение осадков (поле однонаправленных постоянных слабоподвижных водотоков с сезонным колебанием водности). Средой накопления наносов являлся постоянный слабоподвижный извилистый поток равнинного $(\mathrm{Fr}=0,01-0,07)$, реже полугорного грядового $(\mathrm{Fr}=0,10-0,14)$ типа средних рек в благоприятных условиях состояния ложа и течения воды $(\mathrm{n}>37)$ со скоростями сдвига 0,27-0,38 
м/с, скоростями отложения $0,17-0,25$ м/с, скоростями течения $0,29-0,58 \mathrm{~m} / \mathrm{c}$.

Второй ритм (254-263 м) сформирован мелкосреднезернистыми и средне-мелкозернистыми песками с добавлением псаммитовых крупных частиц $(\mathrm{x}=0,16-0,63$ мм). Стандартное отклонение $(\sigma=0,27-$ $0,96)$ определяет умеренно-хорошую, реже - недостаточную отсортированность осадков. Кроме того, мода сдвинута в сторону крупных частиц, эксцесс в большинстве случаев имеет знак «+». Значения коэффициента вариации песков $(v=1,01-1,92)$ указывают на аквальный характер бассейна седиментации и относятся к речному генетическому типу. Палеопотоки имели равнинный $(\mathrm{Fr}<0,1)$ и полугорный $(\mathrm{Fr}=0,1-0,15)$ типы натуральных открытых русел с площадью водосбора $>100$ км $^{2}$ в комфортных условиях пребывания ложа и беспрепятственного движения воды (n>36). Начальным моментом движения наносов в руслах палеорек являлся порог минимальных значений срывающих скоростей водного потока 0,3-0,4 м/с. Аккумуляция начиналась с падением придонной скорости до 0,17 0,25 м/с. Палеорекам были свойственны изменения скоростного режима течения воды от 0,4 до $0,6 \mathrm{~m} / \mathrm{c}$.

В третьем ритме (264-272 м) присутствуют алевриты и тонкозернистые пески $(\mathrm{x}=0,08-0,10 \mathrm{Mм})$ с отдельными более зернистыми песчаными прослоями. Показатель сортировки определяет, как ее очень хорошее качество $\sigma=0,06$, так и реже умеренное, до недостаточного $\sigma=0,35-0,55$. Положительные параметры эксцесса указывают на постоянство тектонических условий седиментации, устойчивое поступление нового дезинтегрированного вещества. Значения коэффициента вариации песков $(v=0,71-0,80)$ соответствуют аквальной среде осадконакопления и относятся к комплексному лимно-аллювиальному генотипу. Кроме того, на интервалах глубины разреза 265 и 268 м отложения имеют речное происхождение $(v=1,32-$ 1,76). Осадки формировались в озеровидных неглубоких (до 1,5 м) проточных водоемах с притоками, имевшими натуральные свободно мигрировавшие русла равнинного $(\mathrm{Fr}=0,03-0,10)$ типа с беспрепятственным течением воды и площадью водосбора $>100$ км². Состоянию ложа были свойственны благоприятные условия $(\mathrm{n}>40)$ при недалеком нахождении речных устьев от водоприемного бассейна $(\Lambda=1,54-2,70)$. Сдвигающие скорости колебались в пределах $0,27-$ 0,35 м/с, предельные скорости накопления - 0,19-0,22 $\mathrm{M} / \mathrm{c}$, поверхностные скорости течения - 0,4-1,0 м/с.

В четвертом ритме (273-280 м) преобладают крупно-мелко-среднезернистые пески $(x=0,19-0,55$ мм), обладающие переменчивой сортировкой - от хорошей до плохой $(\sigma=0,18-1,90)$, положительными, как модальным сдвигом, так и параметрами эксцесса. Коэффициент вариации определяет речной генезис данного ритма ( $v=0,81-1,97)$. Слабоподвижным водотокам по числу Фруда был присущ полугорный $(\mathrm{Fr}>0,1)$ в меньшей степени равнинный $(\mathrm{Fr}<0,1)$ тип стабильных, хорошо оформленных русел с водосборной площадью $>100$ км$^{2}$ и свободным течением воды в придельтовом $(\Lambda=1,4-1,9)$ положении состояния ложа с беспрепятственной поступательной динамикой воды (n=36-46). В фациальном отношении осадки принадлежат речной макрофации (русловая группа).

В пятом ритме (281-290 м) присутствует чередование тонко-мелкозернистых ( $\mathrm{x}=0,08-0,16$ мм) (смешанного генезиса, $v=0,77-0,8)$ и средне-грубозернистых $(\mathrm{x}=0,21-0,96$ мм) (речного происхождения, $v=1,04-1,77)$ песков. Псаммиты имеют плюсовой эксцесс. На интервале 288-290 м в нижней части ритма залегают осадки пролювиального и склонового генезиса $(v=2,19-4,84)$. Средой седиментации отложений комплексного и аллювиального происхождения являлись водотоки равнинного $(\mathrm{Fr}<0,1)$, реже полугорного $(\mathrm{Fr}=0,1-0,2)$ типов натуральных открытых русел с площадью водосбора $>100 \mathrm{kм}^{2}$, находящихся в комфортных условиях пребывания ложа и беспрепятственного движения воды (n>33). Малые значения $\varphi$ критерия устойчивости русел (<100 единиц) характеризуют исследуемые флювиальные системы как немобильные, которые вряд ли могли осуществлять масштабную разрушительную работу по изменению гидрографической сети.

В шестом ритме (291-302 м) имеют место алевритово-мелкозернистые пески $(\mathrm{x}=0,12-0,15$ мм), как комплексного (291-295 м; $v=0,58-0,73)$, так и речного генезиса (300-302 м; v=1,56-1,76) с добавлением материала неаллювиального происхождения (296-299 м; $v=2,44-3,14)$. Порода обладает переменной сортировкой, левосторонней скошенностью эмпирического полигона распределения $(\alpha>1)$, положительным эксцессом. Осадки озерно-аллювиального генезиса аккумулировались в проточных озеровидных объектах с небольшими глубинами (до 2,1 м). Речные отложения формировались немобильными $(\varphi<100)$ равнинными $(\mathrm{Fr}<0,1)$ водотоками с водосборной площадью $>100$ $\mathrm{kм}^{2}$, которые находились в естественных, благоприятных условиях расположения ложа со свободным поступлением воды (n>40). Вычисленные параметры числа Лохтина $(\Lambda=2,1-2,2)$ указывают на приближение исследуемых потоков к конечному водоему.

Самой нижней вскрытой части разреза (интервал 302-352 м) свойственно то же послойное чередование алевритов, алевритсодержащих пород и разнозернистых песков, отличающихся своим происхождением (рис. 4, б). Установлена следующая последовательность формирования осадков.

Первый (303-312 м) и третий (324-337 м) ритмы содержат преимущественно средне-мелкозернистые пески с добавлением гравия и мелкой гальки ( $\mathrm{x}=0,11-$ 0,94). Порода обладает хорошей, умеренной и плохой сортировкой $(\sigma=0,20-1,69)$. Коэффициент асимметрии $\alpha$ положителен в пределах первых единиц. Параметры эксцесса $\tau$, в свою очередь, тоже больше нуля. Данное сочетание статистических значений устанавливает тектонический стабильный характер протекания седиментогенеза в среде, обладавшей повышенным энергетическим потенциалом. Коэффициент вариации 
$v$ находится в пределах от 1,10 до 1,99 единиц и указывает на аллювиальное происхождение осадков. По числу Фруда $(\mathrm{Fr}=0,01-0,21)$ водотоки имели равнинный и полугорный типы палеорусел с развитыми аккумулятивными формами с территорией водосбора не

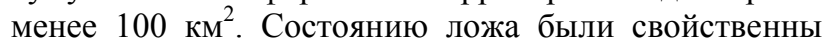
благоприятные условия $(\mathrm{n}=33,68-47,85)$ при недалеком впадении в конечный водоем $(\Lambda=1,31-2,33)$. Имел место переходный режим осаждения, сальтационный перенос, а также донное волочение.

Второй (312-323 м) и четвертый (338-346 м) ритмы - алевриты и пески $(\mathrm{x}=0,07-1,76)$ с очень хорошей, умеренной и плохой сортировкой $(\sigma=0,05-2,59)$, левосторонним смещением моды осадка к его медиане $(\alpha>1)$, положительным эксцессом и значениями коэффициента вариации $(v=0,66-0,80)$, соответствующие области смешанного происхождения с горизонтами речных псаммитов $(v=1,37-1,93)$. $\varphi$-критерий устойчивости речных систем, величина которого не превышает 33 единиц, характеризует русла этих потоков, как слабоподвижные. Значения числа Лохтина свидетельствуют о придельтовых условиях - приближении исследуемых водных систем к конечному водоему, которые имели равнинный $(\mathrm{Fr}<0,1)$, реже полугорный $(\mathrm{Fr}=0,1-0,3)$ типы натуральных открытых

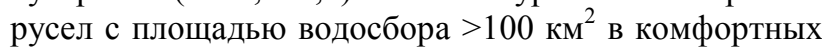
условиях пребывания ложа и беспрепятственного движения воды (n>30) со скоростями доставки частиц 0,26-0,57 м/с, придонными скоростями аккумуляции 0,17-0,36 м/с, поверхностными скоростями течения $0,29-0,93 \mathrm{~m} / \mathrm{c}$.

Пятый ритм (347-352 м) представлен аллювиально-озерными песчаными алевритами $(v=0,66-0,79)$. Стандартное отклонение $(\sigma=0,05-1,6)$ определяет сортировку осадка как очень хорошую, хорошую и умеренно-недостаточную. Свойственны: асимметричный доминантный модальный сдвиг в сторону крупных частиц $(\alpha>1)$, а также стабильное протекание процессов эндогенеза $(\tau>0)$. Средой аккумуляции осадков являлся лимнический проточный водоем с глубинами до 1,5 м, в который дезинтегрированное вещество транспортировалось блуждающими средними водотоками равнинного $(\mathrm{Fr}=0,01-0,03)$ типа с естественными

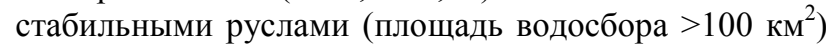
в благоприятных условиях состояния ложа и течения воды $(\mathrm{n}>40)$ при близком впадении в конечный водоем $(\Lambda=1,90-2,74)$. По $\varphi$-критерию устойчивости такие палеопотоки определяются как слабоподвижные со скоростями доставки частиц 0,27-0,30 м/с, придонными скоростями аккумуляции 0,17-0,19 м/с, поверхностными скоростями течения 0,29-0,39 м/с.

Отложения в интервале 353-355 м состоят из аллювиальных $(v=0,85-1,65)$ крупно-среднезернистых песков ( $\mathrm{x}=0,64-0,90$ мм) с небольшими включениями гравия и мелкой гальки. Наблюдается ухудшение сортировки к низу интервала (от умеренной и недостаточной до плохой, $\sigma=0,55-1,49)$. Плюсовой коэффициент асимметрии определяет лучшую сортировку крупнозернистых фракций ( $\alpha=4-7$ единиц). Значения эксцесса $(\tau=31,82-56,82)$ характеризуют устойчивое состояние вещества на всем протяжении периода осадконакопления при относительно спокойном тектоническом режиме.

Потокам, образовавшим описываемый слой, был свойствен преимущественно полугорный тип русел с развитыми грядовыми подвижными формами донного рельефа $(\mathrm{Fr}=0,15-0,21)$ и площадью водосбора $>100$ км $^{2}$. Скорости водотоков составляли 0,60-0,69 м/с. В фациальном плане подобные условия характерны для русловых фаций речной макрофации.

\section{Заключение}

Накопление плейстоценовых отложений в Баргузинской долине отразило образование оз. Байкал в результате быстрого некомпенсированного осадками погружения ложа впадин и тектонических подпоров речного стока, вызывавших подъем уровня и ингрессии вод в межгорные понижения. Быстрое опускание ложа озера запечатлено в накоплении ритмичной толщи Баргузинской долины, тектонические подпоры речного стока - в образовании перекрывающей песчаной толщи.

Плейстоценовые преимущественно субгоризонтально-слабонаклонно-слоистые алевритово-песчаные отложения аквального генезиса увала Верхний Куйтун имеют мощность 527 м в естественном обнажении высотой 172 м и вскрытом интервале скв. 538 до глубины 355 м.

Результаты палеопотамологического анализа отложений увала Верхний Куйтун свидетельствуют об их формировании в мелководных, достаточно крупных, проточных лимнических водоемах с малоамплитудным характером волновых колебаний и разветвленной сетью придонных течений, выразившихся в распространении субгоризонтально-слоистых алевритово-тонкопесчаных береговых и прибрежных фаций лимнической макрофации. Речные потоки были однонаправленными слабодинамичными и немобильными с замедленным движением воды ввиду их подпора в придельтовом положении русел с появлением наклонно-, реже косослоистых мелко-среднезернистых песков русловых и пойменных фаций речной макрофации.

Судя по ориентировочной термолюминисцентной датировке около 140 тыс. лет [7], песчаные отложения Верхнего Куйтуна накапливались с финала среднего неоплейстоцена, до проявления Тыйской тектонической фазы структурной перестройки рельефа. Предшествующая ритмичная толща Баргузинской долины сформировалась во временном интервале с 3-2 млн. лет назад до 0,14 млн. лет назад.

Работы выполнены при финансировании грантом РФФИ № 18-35-00417 мол а. 


\section{ЛИТЕРАТУРА}

1. Логачев, H. А. Саяно-Байкальское становое нагорье / Н. А. Логачев // Нагорья Прибайкалья и Забайкалья. - М. : Наука.- 1974.- С. 7-163.

2. Зорин, Ю. А. Новейшая структура и изостазия Байкальской рифтовой зоны и сопредельных территорий / Ю. А. Зорин.- М. : Наука, 1971.- 168 с.

3. Logatchev, N. A. Baikal rift zone: structure and geodynamics / N. A. Logatchev, Yu. A. Zorin // Tectonophysics. - 1992. V. 208. - P. 273-286.

4. Конева, В. И. Отчет о результатах бурения Баргузинской опорной скв. Р-1. / В. И. Конева.- Востсибнефтегеология.Иркутск, 1955.

ФГБОУ ВО Иркутский государственный университет, Университет Аль-Басс, город Хомс, Сирия

Хассан Абдулмонем Исса, аспирант геологического факультета ИГУ, ассистент, геологическое отделение, факультет естественных наук

Email: abdulmonemhassan86@gmail.com

Тел.: +7 (3952) 201639

ФГБУН Геологический институт СО РАН, г. Улан-Удэ ФГБОУ ВО Бурятский государственный университет, г. Улан-Удэ

Коломиеи Владимир Леонидович, кандидат геологоминералогических наук, старший научный сотрудник, доиент кафедры геологии

E-mail: kolom@ginst.ru; Тел.: +7(3012) 433955

ФГБУН Институт земной коры СО РАН, Иркутск ФГБОУ ВО Иркутский государственный университет

Рассказов Сергей Васильевич, доктор геологоминералогических наук, заведующий кафедрой динамической геологии ИГУ, профессор, заведующий лабораторией изотопии и геохронологии

E-mail: rassk@crust.irk.ru; Тел.: +7 (3952) 511659

ФГБУН Геологический институт СО РАН, г. Улан-Удэ

Будаев Ринчин Цыбикжапович, кандидат геологоминералогических наук, старший научный сотрудник E-mail: budrin@ginst.ru; Тел.:+7(3012)433955

ФГБУН Институт земной коры СО РАН, г. Иркутск ФГБОУ ВО Иркутский государственный университет

Чувашова Ирина Сергеевна, кандидат геологоминералогических наук, доцент кафедры динамической геологии, стариий научный сотрудник

E-mail: chuvashova@crust.irk.ru; Тел.: +7 (3952) 511659

ФГБОУ ВО Иркутский государственный университет Университет Аль-Фурат, Дейр-Эз-Зор, Сирия

Аль Хамуд Аднан, аспирант геологического факультета ИГУ. Ассистент, геологическое отделение, факультет естественных наук Университет Аль-Фурат, Дейр-Эз-Зор, Сирия

E-mail: hamoudadnan04@gmail.com; Тел.: +7 (3952) 201639
5. Исаев, В. П. Природные газы Баргузинской впадины / В. П. Исаев.- Иркутск. - Иркутск : Изд-во Иркут. гос. ун-та, 2006. -220 c.

6. Коломиеи, В. Л. Реконструкции параметров палеопотоков по ископаемым осадкам / В. Л. Коломиец // Вестник Бурятского университета. Серия 3: география, геология. Вып. 2. - Улан-Удэ: Изд-во БГУ, 1998. - С. 92-100.

7. Kolomiets, V. L. Barguzin rift valley: Sedimentogenesis and paleogeography (Baikalian area, Russia) / V. L. Kolomiets, R. Ts. Budaev // Quaternary International. - V. 355. - 2015. - P. 57-64. http://dx.doi.org/10.1016/j.quaint.2014.09.017

8. Мач, В. Д. Кайнозой Байкальской рифтовой впадины: строение и геологическая история / В. Д. Мац [и др.]. - Новосибирск: Изд-во СО РАН, филиал «Гео», 2001. - 252 с.

Irkutsk State University, Irkutsk

Al-Baath University, Homs, Syria

Abdulmonem Issa Hassan, Graduate student ISU Geological

Faculty, Assistant Department of Geology, Faculty of Science

Email:abdulmonemhassan86@gmail.com

Tel.: +7 (3952) 201639

Geological Institute SB RAS, Ulan-Ude

D. Banzarov Buryat State University, Ulan-Ude

Kolomiets V. L., Candidate of the Geological and Mineralogical Sciences, Senior Researcher, Associate Professor

E-mail:kolom@ginst.ru

Tel.: +7(3012) 433955

Institute of the Earth's Crust, Siberian Branch of RAS, Irkutsk Irkutsk State University, Irkutsk

Rasskazov S. V., Head of the Department of dynamic geology, Doctor of Geological and Mineralogical Sciences, Head of Laboratory for Isotopic and Geochronological Studies

E-mail:rassk@crust.irk.ru

Tel.: +7 (3952) 511659

Geological Institute SB RAS Ulan-Ude

Budaev R.Ts., Candidate of the Geological and Mineralogical Sciences, Senior Researcher

E-mail: budrin@ginst.ru

Tel.: +7(3012) 433955

Institute of the Earth's Crust, Siberian Branch of RAS, Irkutsk Irkutsk State University, Irkutsk

Chuvashova I. S., Candidate of the Geological and Mineralogical Sciences, associate professor, Department of dynamic geology, Senior Researcher

E-mail:chuvashova@crust.irk.ru

Tel.: +7 (3952) 511659

Irkutsk State University, Irkutsk

Al-Furat University, Syria

Adnan Al Hamoud, Graduate student ISU Geological Faculty. Assistant Department of Geology, Faculty of Science, Al-Furat University

E-mail: hamoudadnan04@gmail.com

Tel.: +7 (3952) 201639 